Available online at_www.iponlinejournal.com

\title{
Health perceptions and priorities among young men in Surat city: Workshop findings
}

\author{
Shiv Kumar Yadav ${ }^{1}$, JK Kosambiya ${ }^{2 *}$, Zeel Kamdar ${ }^{3}$, Saurabh Parmar $^{4}$, Alpesh Gohil ${ }^{5}$, Rutu Buch ${ }^{6}$, Mohua Moitra ${ }^{7}$, \\ Sangeeta S Dave ${ }^{8}$
}

${ }^{1}$ Assistant Professor, ${ }^{2}$ Professor, ${ }^{3}$ State Epidemiologist, ${ }^{4}$ Program Officer, ${ }^{5}$ Senior Clinical Trainer, ${ }^{6}$ Tutor, ${ }^{7}$ Associate Professor, ${ }^{8}$ Honorary Senior Lecturer, ${ }^{\mathbf{1 , 2 , 6 , 7}}$ Dept. of Community Medicine, ${ }^{1}$ Government Doon Medical College, Dehradun, Uttarakhand, ${ }^{\mathbf{2}, \mathbf{7}}{ }^{\mathrm{7}}$ Government Medical College, Surat, Gujarat, ${ }^{3}$ State TB Diagnostic and Research Centre (RNTCP), Gujarat, ${ }^{4}$ Jhapiego, ${ }^{5}$ Engender Health Office, Ahmedabad, Gujarat, ${ }^{8}$ University College London, United Kingdom

\begin{abstract}
Adolescence is an important phase of development. Health behaviours acquired during this period, such as smoking, drinking alcohol, illicit drug use and risky sexual activity can affect health adversely, including when older. Mental health problems are also common in this age group. 1 However, the global focus has only recently moved onto adolescents and young people. 2 The WHO call for global in 2002 was followed by many countries implementing adolescent health programmes. 3 In India, as in many countries, most programmes focus on adolescent girls' sexual and reproductive health. 4 Although young men aged 15 to 24 years account for $10 \%$ of India's population, their health needs are mostly unmet.5 We conducted workshops in slum areas of an industrial city, Surat, in Gujarat to explore young men's perceptions of health and health priorities and gain a better understanding of their access to health-related information and care..
\end{abstract}

Keywords: S, drinking alcohol, Illicit drug use and risky sexual activity can affect health adversely, Including when older.

\section{Introduction}

Adolescence is an important phase of development. Health behaviours acquired during this period, such as smoking, drinking alcohol, illicit drug use and risky sexual activity can affect health adversely, including when older. Mental health problems are also common in this age group. However, the global focus has only recently moved onto adolescents and young people. ${ }^{2}$ The WHO call for global in 2002 was followed by many countries implementing adolescent health programmes. ${ }^{3}$ In India, as in many countries, most programmes focus on adolescent girls' sexual and reproductive health. ${ }^{4}$ Although young men aged 15 to 24 years account for $10 \%$ of India's population, their health needs are mostly unmet. ${ }^{5}$ We conducted workshops in slum areas of an industrial city, Surat, in Gujarat to explore young men's perceptions of health and health priorities and gain a better understanding of their access to health-related information and care.

\section{Materials and Methods}

We carried out field visits and community discussions within Surat city to gain a better understanding of young men's health concerns. Based on this information, we conducted five workshops between December 2013 and January 2014 in urban health centres in Udhna, Limbayat and Godadara, areas with a high proportion of slumdwellers within the city. Male participants from the localities were invited to participate by field workers. Separate workshops in each area were conducted for 16 to 19 year old (younger men) and 20 to 24 year old men (older men). We were unable to recruit enough men to conduct a workshop for the latter age group in Limbayat. We recruited 50 participants in total; ten in each of the remaining groups. Each workshop lasted three and a half hours and was facilitated by two junior doctors supervised by senior doctors using a proforma. Following written consent, the workshops were conducted in Hindi, the national language and Gujarati, the regional language.

The workshop was divided into four topics: general health; cigarette, alcohol and drug use; mental health and sexual health. Each topic was sub-divided into areas as discussed below in the results section. We used free listing, given topics, group discussion and consensus to rank the responses in order of importance obtain data. Due to lack of time, we did not ask the younger aged participants in Limbayat about facilitators and barriers to health. We present the most common five answers given by participants to each question in the results section below.

\section{Results}

"What is health?"

In older and younger men, absence of disease was ranked as the most important answer. This was followed by absence of malnutrition, and lack of addiction. Health was also said to be necessary, priceless and led to a good personality.(Table 1)

\section{Health problems in young men General health}

In order of importance, participants in both age groups ranked accidents as the most important problem for young men and addiction to alcohol, tobacco and drugs as the third most important problem. Both groups also included fever

\footnotetext{
*Corresponding Author: JK Kosambiya, Dept. of Community Medicine, Government Medical College, Surat, Gujarat, India

Email: jkkosambiya@gmail.com
}

http://doi.org/10.18231/J.IJFCM.2019.043 
and malaria, ranked second and fifth, and concerns about personal appearance, ranked fifth and second, by younger and older men respectively. The terms "fever" and "malaria" were used interchangeably. Older men ranked mental health concerns and younger men anaemia fourth.(Table 2)

\section{Sexual health}

Older and younger participants ranked itching in the genital area as the most important male sexual health problem followed by genital ulcers/sores and a change in libido. Younger men ranked night fall, ejaculation during sleep, and older men, premature ejaculation, fourth. Both age groups ranked burning micturition fifth; older men ranked sexually transmitted infections joint fifth.(Table 3)

\section{Mental health}

In younger men, stress due to exams and homework was ranked the most important problem for young men. This was followed by a change in appetite due to stress, negative or "dirty" thoughts, uncontrolled thoughts and emotional disturbance and a change in sleep. In older men, the most important reason for mental health problems was ranked as stress due to job insecurity followed by anxiety and emotional disturbance, competitiveness, insecurity about the future and negative, uncontrolled thoughts. (Table 4)

\section{Alcohol, drugs and cigarettes}

Both age groups gave similar responses, ranking ill health and wasting money as the two most important problems. This was followed by effect on work performance, and behaviour and relationships. Younger men ranked mental disorder and older men problems with the law fifth. (Table 5)

Health problems in young women

Table 1: Responses to "what is health?"

\begin{tabular}{|c|c|c|}
\hline $\begin{array}{c}\text { Rank by } \\
\text { priority }\end{array}$ & $\mathbf{1 6 - 1 9}$ years old men & $\mathbf{2 0 - 2 4}$ years old men \\
\hline $1^{\text {st }}$ & $\begin{array}{c}\text { Health is absence of disease "koi bimari nahi hain to } \\
\text { swasth hain" ("No disease means healthy person") }\end{array}$ & Health is absence of disease \\
\hline $2^{\text {nd }}$ & Absence of malnutrition & Absence of malnutrition \\
\hline $3^{\text {rd }}$ & Absence of addiction & Absence of addiction \\
\hline $4^{\text {th }}$ & Health is necessary & Health is necessary \\
\hline $5^{\text {th }}$ & Health is priceless & Good health gives good personality \\
\hline
\end{tabular}

Table 2: Perceptions about general health problems in young men

\begin{tabular}{|c|c|c|}
\hline $\begin{array}{l}\text { Rank by } \\
\text { priority }\end{array}$ & 16-19 years old men & 20-24 years old men \\
\hline $1^{\mathrm{st}}$ & $\begin{array}{c}\text { Road accidents “Cycle, bike se girte rahte hain" } \\
\text { ("Accidents happens frequently while driving } \\
\text { cycles and bikes") }\end{array}$ & Road accidents \\
\hline $2^{\text {nd }}$ & Fever /Malaria & $\begin{array}{l}\text { Dissatisfaction related to Physical appearances } \\
\text { "Har koi accha dikhna chahta hain”" } \\
\text { ("Everyone wants to look good") }\end{array}$ \\
\hline $3^{\text {rd }}$ & $\begin{array}{l}\text { Addiction to Alcohol/ Tobacco/Illicit drugs } \\
\text { “Mostly sab log nashi karna start kar dete hain.” }\end{array}$ & Addiction to Alcohol/Tobacco/Illicit drugs \\
\hline
\end{tabular}




\begin{tabular}{|c|c|c|}
\hline & ("Majority start indulging in addictive habits") & \\
\hline $4^{\text {th }}$ & Anaemia & Mental health problems \\
\hline $5^{\text {th }}$ & Physical appearances & Fever /Malaria \\
\hline
\end{tabular}

Table 3: Perceptions about sexual health problems in young men

\begin{tabular}{|c|c|c|}
\hline $\begin{array}{c}\text { Rank by } \\
\text { priority }\end{array}$ & $\mathbf{1 6 - 1 9}$ years old men & $\mathbf{1 9 - 2 4}$ years old men \\
\hline $1^{\text {st }}$ & $\begin{array}{c}\text { Itching in genital area "jyada der bethe rahte to } \\
\text { pasine se khujli hoti hain" " "prolonged sitting } \\
\text { leads to excessive sweating which causes itching") }\end{array}$ & Itching in genital area \\
\hline $2^{\text {nd }}$ & Genital ulcer/sore & Genital ulcer/sore \\
\hline $3^{\text {rd }}$ & Change in libido & Change in libido \\
\hline $4^{\text {th }}$ & Night fall (ejaculation during sleep) & Premature ejaculation \\
\hline $5^{\text {th }}$ & Burning micturition & Burning micturition/sexually transmitted infections \\
\hline
\end{tabular}

Table 4: Perceptions about mental health problems in young men

\begin{tabular}{|c|c|c|}
\hline $\begin{array}{r}\text { Rank by } \\
\text { priority }\end{array}$ & 16-19 years old men & 20-24 years old men \\
\hline $1^{\mathrm{st}}$ & Stress due to exams and homework & Stress due to job insecurities \\
\hline $2^{\text {nd }}$ & $\begin{array}{c}\text { Change in appetite "Tension ki wajah se bhook bhi kam ya } \\
\text { jyada lagti hain"(There is an increase or decrease in } \\
\text { appetite due to stress) }\end{array}$ & $\begin{array}{l}\text { Anxiety and emotional disturbances } \\
\text { "Hamesha chinta rehti hain or dimaag } \\
\text { kharab rahta hain" ("There is always } \\
\text { anxiety and bad moods") }\end{array}$ \\
\hline $3^{\text {rd }}$ & $\begin{array}{c}\text { Negative thoughts "Bade hi gande or dravne vichhar aate } \\
\text { hain" } \\
\text { ("The mind is occupied with dirty and negative thoughts") }\end{array}$ & $\begin{array}{l}\text { Competitiveness "Kisi tarah ek dusre se } \\
\text { aag enikle ne ki sochte rahte hain" } \\
\text { ("He is always thinking about how to get } \\
\text { ahead of others by any means.") }\end{array}$ \\
\hline $4^{\text {th }}$ & Uncontrolled thoughts/emotional disturbance & $\begin{array}{c}\text { Insecurity "Future ki tension rahti hain" } \\
\text { ("We are worried about future") }\end{array}$ \\
\hline $5^{\text {th }}$ & Change in amount of sleep & Negative or uncontrolled thoughts \\
\hline
\end{tabular}

Table 5: Perceptions about health problems related to cigarettes, alcohol and illicit drug use

\begin{tabular}{|c|c|c|}
\hline $\begin{array}{c}\text { Order } \\
\text { of priority }\end{array}$ & 16-19 years old men & 20-24 years old men \\
\hline $1^{\mathrm{st}}$ & $\begin{array}{c}\text { Ill health "jo nashi karta hain wo bimaar rahate hain" } \\
\text { ("addictions leads to ill health") }\end{array}$ & $\begin{array}{c}\text { Money wastage "paiso ki bigaad bahut hoti } \\
\text { hain" ("Huge wastage of money occurs due } \\
\text { to addictions") }\end{array}$ \\
\hline $2^{\text {nd }}$ & Money wastage & Ill-health \\
\hline $3^{\text {rd }}$ & $\begin{array}{c}\text { Effect on work performance "nashi karne waale ka } \\
\text { mann kaam main nhi lagta" ("addictions leads to loss } \\
\text { of interest in work") }\end{array}$ & Effect on behaviour/relations \\
\hline $4^{\text {th }}$ & $\begin{array}{c}\text { Effect on behaviour/ relations "jo nasha karta hain wo } \\
\text { kisi ki nahin sunte" } \\
\text { ("addicted people do not listen to anyone") }\end{array}$ & Effect on work performance \\
\hline $5^{\text {th }}$ & Mental disorder & Problems related to law \\
\hline
\end{tabular}

Table 6: Perceptions about general health problems in young women

\begin{tabular}{|c|c|c|}
\hline $\begin{array}{c}\text { Rank by } \\
\text { priority }\end{array}$ & $\mathbf{1 6 - 1 9}$ years old men & $\mathbf{1 9 - 2 4}$ years old men \\
\hline $1^{\text {st }}$ & Family planning & Menstruation problems \\
\hline $2^{\text {nd }}$ & Menstruation problems & Dissatisfaction related to Physical appearances \\
\hline $3^{\text {rd }}$ & $\begin{array}{c}\text { Pregnancy related problems - } \\
\text { unwanted, avoiding pregnancies }\end{array}$ & $\begin{array}{c}\text { Pregnancy related problems-unwanted, avoiding } \\
\text { pregnancies }\end{array}$ \\
\hline $4^{\text {th }}$ & Anaemia & Childbirth related problems \\
\hline $5^{\text {th }}$ & Mental health & Anaemia \\
\hline
\end{tabular}


Table 7: Perceptions about sexual health problems in young women

\begin{tabular}{|c|c|c|}
\hline Rank by priority & $\mathbf{1 6 - 1 9}$ years old men & 19-24 years old men \\
\hline $1^{\text {st }}$ & Menstruation related problems & Menstruation related problems \\
\hline $2^{\text {nd }}$ & Itching in genital area & Fear of pregnancy \\
\hline $3^{\text {rd }}$ & Fear of pregnancy & Itching in genital area \\
\hline $4^{\text {th }}$ & Family planning & Burning micturition/sexually transmitted infections \\
\hline $5^{\text {th }}$ & Fear of disclosure of pre-marital affairs & Fear of disclosure of extra-marital affairs \\
\hline
\end{tabular}

Table 8: Perception about barriers to young men accessing healthcare

\begin{tabular}{|c|c|c|}
\hline $\begin{array}{l}\text { Rank by } \\
\text { priority }\end{array}$ & 16-19 years old men & 20-24 years old men \\
\hline 1 st & $\begin{array}{l}\text { Lack of money/money is essential for having good } \\
\text { health. "paise ke bina koi illaz nhin kara sakte" } \\
\text { ("No treatment can occur without money") }\end{array}$ & $\begin{array}{l}\text { Lack of money/money is essential for having good } \\
\text { health. "Paise bahut jarrori hain illaz ke liye." } \\
\text { ("Money is very necessary to have treatments") }\end{array}$ \\
\hline $2^{\text {nd }}$ & $\begin{array}{c}\text { Distance from health facility } \\
\text { "Hospital door ho to koi ilaaz nahi karate” } \\
\text { ("Nobody can access the treatment if the hospital } \\
\text { is far away.") }\end{array}$ & $\begin{array}{l}\text { Distance from health facility "Hospital door ho to } \\
\text { time nahi milta jaane ke liye" ("If a hospital is far } \\
\text { away, there is not enough time to go to it.") }\end{array}$ \\
\hline $3^{\text {rd }}$ & There is not enough time to go to the doctor & There is not enough time to go to the doctor \\
\hline $4^{\text {th }}$ & $\begin{array}{l}\text { There is a lack of Information regarding } \\
\text { healthcare facilities “Pata nahi hota } \boldsymbol{k a h a} \text {, } \\
\text { kab, } \boldsymbol{k a i s e} \text { jaye hospital” (We don't know where, } \\
\text { how and when to access health care.") }\end{array}$ & The rude behaviour of doctors \\
\hline $5^{\text {th }}$ & $\begin{array}{c}\text { The rude behaviour of doctors "Doctor acche se } \\
\text { baat nahin karta" } \\
\text { ("Doctors don't behave properly.") }\end{array}$ & $\begin{array}{l}\text { Lack of Information regarding available healthcare } \\
\text { facilities }\end{array}$ \\
\hline
\end{tabular}

Table 9: Perception about barriers to young women accessing healthcare

\begin{tabular}{|c|c|c|}
\hline $\begin{array}{c}\text { Rank by } \\
\text { priority }\end{array}$ & $\mathbf{1 6 - 1 9}$ years old men & 19-24 years old women \\
\hline 1 st & $\begin{array}{c}\text { Lack of Time due to chores "Itna kaam hota hain } \\
\text { ki time hi nahin milta" ("There is so much work to } \\
\text { do, she does not even get the time") }\end{array}$ & Lack of time to access health services \\
\hline $2^{\text {nd }}$ & $\begin{array}{c}\text { Fear of disclosure related to illness among family } \\
\text { members "Gharwaale daat maarenge isiliye } \\
\text { bimari batate nahin" "'She won't tell her family } \\
\text { members about her illness in case they beat her.") }\end{array}$ & $\begin{array}{c}\text { Fear of disclosure of illness among family } \\
\text { members, especially in-laws. }\end{array}$ \\
\hline $3^{\text {rd }}$ & $\begin{array}{c}\text { Lack of money /money is essential for good health. } \\
4^{\text {th }}\end{array}$ Lack of information regarding healthcare facilities. & $\begin{array}{c}\text { Fear of breach of confidentiality about illness “Aas } \\
\text { padosh } \text { ke logo } \text { ko pata chal gaye bimarika to? " } \\
\text { Lack of Information regarding healthcare facilities. }\end{array}$ \\
\hline $5^{\text {th }}$ & The rude behaviour of doctors & The rude behaviour of doctors \\
\hline
\end{tabular}

\section{Discussion}

Both age groups had similar perceptions about what health meant and problems related to health in general and specifically, mental health, alcohol, cigarette and illicit drug use and sexual behaviour. Health was mainly thought to be an absence of disease.

Younger and older men said that the main problem for health generally for young men was road traffic accidents, reflecting an awareness of a recognised problem of their vulnerability on the road in low and middle-income countries. ${ }^{2}$ Although their responses included malaria, fever, anaemia and mental health problems, they did not mention sexual health problems. Physical appearance concerns were important among the older participants.
However, when discussing sexual health specifically, both age groups talked about symptoms and signs of sexually transmitted infections such as genital ulcers, sores and burning micturition (pain on passing urine). Older men stated sexually transmitted infections were a problem and also prioritised premature ejaculation. A recent survey shows high levels of risky sexual behaviour among men, including young men, in India. ${ }^{6}$

Participants in both age groups thought young men were affected by stress and emotional problems. The older age group thought competitiveness and concerns about future insecurity were also important. Mental health problems may first become apparent in adolescence ${ }^{1}$ and India has among the highest suicide death rates in the world. $^{7}$ 
Addiction to alcohol, cigarettes and illicit drugs was thought to cause unspecified ill-health, mental health problems and affect young men's performance at work and socially. The highest rates of tobacco use are in adolescents in low and middle-income countries, such as India. ${ }^{8}$

Young men talked about family planning whereas older men talked about childbirth as problems for young women, suggesting the men were more likely to be married. Younger men also thought mental health issues and anaemia were problems for young women. Anaemia is thought to be present in more than half the girls in India aged 15 to 19 years. ${ }^{3}$ Fear of pregnancy, sexually transmitted infections and fear of disclosure of pre- and extra-marital affairs were also thought to be problems for young women, possibly reflecting the participant's own worries and experiences.

Both age groups ranked lack of money, information about health care facilities, time and doctors' rude behaviour as barriers to accessing health care for young men and women. In addition, for young men, the distance to a clinic was a problem. Whereas for women, lack of time and lack of confidentiality with family members were issues. These concerns of lack of confidentiality, behaviour of healthcare staff and inability to pay for healthcare are similar to reproductive health service access study results in India. ${ }^{9,10}$ Decreased opportunities for access due to limited mobility and power to make independent decisions have also been shown. ${ }^{11}$

Our exploratory findings suggest young men across the 16 to 19 years age group and 20 to 24 years age group have similar perceptions about health, although their priorities can differ and the lack of prioritisation of sexually transmitted infections is of concern. They have high levels of stress and some knowledge about young women's health problems. There appear to be many barriers to young men accessing health care. We recommend further research on their health and facilitators and barriers to health care access.

\section{Acknowledgment}

We acknowledge University College London, UK for financial support and PARAS PSM Project Staff for field level management.

\section{Source of Funding}

None.

\section{Conflict of Interest}

None.

\section{References}

1. Adolescent Friendly Health Services - an Agenda for Change WHO/FCH/CAH/02004@ World Health Organization October 2002

2. Patton GC, Sawyer SM, Santelli JS et al. Our future: a Lancet commission on adolescent health and well-being. Lancet 2016; 387: $2423-78$

3. UNICEF. State of the world's children 2011: adolescence-an age of opportunity. New York, NY: United Nations Children's Fund, 2011

4. A Strategic Approach to Reproductive, Maternal New-born Child Adolescent Health (RMNCH+A).Ministry of Health, Got of India, January 2013.

5. Census of India 2011. Population enumeration Data: p.1 http://www.censusindia.gov.in/

6. Gaffey MF, Venkatesh S, Dhingra N. Male use of female sex work in India: a nationally representative behavioural survey. PLoS One 2011;6(7):e22704. doi:10.1371/journal.pone.0022704

7. Patel V, Ramasundarahettige C,Vijayakumar L. Suicide Mortality in India: a nationally representative survey. Lancet Elsevier 2012;23;379(9834):2343-51.

8. Patton GC, Coffey C, Cappa C. Health of the world's adolescents: a synthesis of internationally comparable data. Lancet 2012;379:1665-75

9. Pachauri S, Implementing a reproductive health agenda in India: The Beginning. New York: Population Council; 1999

10. Sharma A. Reproductive morbidity and health seeking behavior of adolescent women in rural India. Paper presented at Population Association of America Annual Meeting, Boston, Massachusetts, USA: 1-3 April, 2004.

11. Mensch BS, Bruce J, Greene ME. The unchartered passage: Girls' adolescence in the developing world. New York: The Population Council; 1998.

How to cite this article: Yadav SK, Kosambiya JK, Kamdar Z, Parmar S, Gohil A, Buch R, Moitra M, Dave SS. Health perceptions and priorities among young men in Surat city: Workshop findings. Indian $J$ Forensic Community Med 2019;6(3):197-201. 